\title{
Comparative analysis of lung function of rats using a new intubation technique and tracheostomy
}

\section{Análise comparativa da função pulmonar de ratos usando uma nova técnica de intubação e a traqueostomia}

\author{
Daniel Silveira SERRA ${ }^{1}$; Kaio Bruno Pereira de BRITO ${ }^{1}$; Francisco Sales Ávila CAVALCANTE ${ }^{1}$ \\ ${ }^{1}$ Universidade Estadual do Ceará, Instituto Superios de Ciências Bimédicas, Laboratório de Biofísica da Respiração, Fortaleza - CE, Brazil
}

\begin{abstract}
Several studies use intubation or tracheostomy for data collection in lung function of rats. Due to the difficulty of performing intubation, tracheostomy is most commonly used. Knowing this difficulty, this paper demonstrates a new way to perform the intubation technique and compares pulmonary function variables obtained using intubation or tracheostomy. For the analysis of our new technique of intubation, 30 rats were used, and the comparative analysis of lung function data obtained through the use of our technique of intubation and tracheostomy, 16 rats were used, divided into two groups. The T group underwent tracheostomy. The IT group underwent initial intubation and, awaiting recovery, a week later was again subjected to intubation group, which was then called IT-1W. Our intubation technique is performed with the aid of a wedge, inclined bed and percutaneous transillumination. No animals died during the intubation procedure, and about $77 \%$ of the animals were intubated at the first attempt. We did not obtain statistically significant differences in the pulmonary function variables between the groups. Our intubation technique is easily learned and reproduced. The implications of such a technique can be generalized to all laboratories dealing with intubation of rats.
\end{abstract}

Keywords: Intubation. Tracheostomy. Lung function.

\section{Resumo}

Vários estudos utilizam a intubação orotraqueal ou traqueostomia para coleta de dados na função pulmonar de ratos. Devido à dificuldade de realização da intubação, a traqueostomia é mais comumente utilizada. Conhecendo esta dificuldade, este trabalho demonstra uma nova maneira de realizar a técnica de intubação e compara as variáveis de função pulmonar obtidas por intubação ou traqueostomia. Para a análise de nossa nova técnica de intubação, foram utilizados 30 ratos, e para a análise comparativa dos dados da função pulmonar obtidos pelo uso de nossa técnica de intubação e traqueotomia, 16 ratos foram utilizados, divididos em dois grupos. O grupo $\mathrm{T}$ foi submetido a traqueostomia. O grupo de IT foi submetido inicialmente a intubação e, esperada sua recuperação, uma semana depois foi novamente submetido a intubação, que foi então chamado de grupo IT-1W. Nossa técnica de intubação é realizada com a ajuda de uma cunha, cama inclinada e transiluminação percutânea. Nenhum animal morreu durante o procedimento de intubação, e cerca de $77 \%$ dos animais foram intubados na primeira tentativa. Não foram obtidas diferenças estatisticamente significativas nas variáveis de função pulmonar entre os grupos. Nossa técnica de intubação é facilmente aprendida e reproduzida. As implicações de tal técnica podem ser generalizadas para todos os laboratórios que lidam com a intubação de ratos.

Palavras-chave: Intubação. Traqueostomia. Função pulmonar. 
Correspondence to:

Daniel Silveira Serra

Universidade Estadual do Ceará, Laboratório de Biofísica da

Respiração

Av. Paranjana, 1700, Itaperi

CEP 60714-903, Fortaleza, CE, Brazil

e-mail: danielserra@globo.com

Received: 18/08/2015

Approved: 08/09/2016

\section{Introduction}

A large number of experimental models have been developed in animal studies. The rat is often used in experimental research, particularly in experimental surgery, because of its easy availability, low cost and small size (ABRÃO et al., 1994). Regarding use in biomedical research, the number of rats is surpassed only by mice. In these laboratory animals, the presence of a small entrance in the oropharynx, larynx tiny, epiglottis and vocal cords represent a considerable challenge in the control of airways before and after surgery under general anesthesia (ALZABEN et al., 2009).

Due to its larger size, rats are still preferred in studies investigating organ transplants in regenerative medicine and imaging (MACDONALD et al., 2009). Some of these studies use general anesthesia and neuromuscular blocking agents. These agents depress respiration and may induce respiratory arrest, possibly leading to death of the animal.

Tracheostomy is convenient to maintain adequate ventilation during acute experiments with subsequent sacrifice of the animal, but in experiments in which their survival is necessary, closing the surgical wound of tracheostomy can generate complications, making it difficult to perform longitudinal studies. To solve this problem, intubation is more suitable and less damaging, providing the animal survival after surgery. However, due to intubation difficulties, few researchers use repeated measurements to investigate lung cellular or mechanic changes in rats (KASTL et al., 2004).
Aiming at achieving intubation, several techniques are described in the literature, although some require more elaborate equipment specially developed (CLARY et al., 2004; KASTL et al., 2004; KONNO et al., 2014), requiring little prior training and generally achieving high success rates. Other simpler methods, not requiring specific materials, however, require more training and have questionable success rates, as well as injury history in the glottis, larynx and/or vocal cords of animals. Among them can be mentioned: blind intubation (STARK et al., 1981), making a handmade laryngoscope (ABRÃO et al., 1994), use of a specially-developed fiber optic laryngoscope (LINDEN et al., 2000), insertion of wedge in the oral region (JOU et al., 2000), transillumination method (LIZIO et al., 2001), performing of videoendoscopy (KONNO et al., 2014) and use of perpendicular (HAMACHER et al., 2008) or inclined plaque (KASTL et al., 2004; ALZABEN et al., 2009) for fixing the animal.

This paper presents a new technique of intubation compiled from various techniques present in literature. The technique reported here can be performed using only materials that are generally available in the biomedical sciences laboratories, reducing the cost of its operation, making it easy to learn and adequate for wide use.

Analysis of the effectiveness of this new intubation technique was also performed, as well as a comparative study between the results of pulmonary function in rats using the new technique of intubation and tracheostomy as methods for coupling the animal in mechanical ventilator, to check whether the proposed technique can serve as an alternative to tracheostomy without creating change in the data analysis of lung mechanics.

\section{Material and methods}

\section{Animals}

To analyze the efficiency of the new technique of intubation, 30 albino rats, Rattus norvegicus, Wistar 
variety, male, with body weight $300 \pm 70 \mathrm{~g}$ and $\sim 3$ months old were used in this study. Another 16 albino rats, Rattus norvegicus, Wistar variety, male, with body weight $250 \pm 50 \mathrm{~g}$ was used for the comparative analysis of pulmonary function data obtained using intubation technique and tracheostomy. The animals were divided into two groups: the $\mathrm{T}$ group $(\mathrm{n}=8)$ underwent tracheostomy and the IT group $(n=8)$ underwent initial intubation and awaited recovery. A week later, the IT group was again subjected to intubation, and was called the IT-1W group.

All animals were housed in a conventional animal facility and placed in sterile plastic cages the rats had access to food and water ad libitum treated. All experimental procedures are in accordance with the basic principles for research involving the use of animals recommended by the Ethics Committee for
Use in Animals of State University of Ceará.

\section{New technique intubation}

To perform the new technique intubation, the animals were anesthetized with sodium pentobarbital (50 mg/kg, Hypnol 3\% , Syntect, Brazil), intraperitoneally and positioned in supine position, bound to a bed inclined at $30^{\circ}$ by the upper incisors, seeking a straight placement between its head, neck and chest, to facilitate the visualization of the trachea.

A wedge made from a $3 \mathrm{~mL}$ syringe, consisting of a front side with $1 \mathrm{~cm}$ in length, a rear side with an angle of $25^{\circ}$, with $1.5 \mathrm{~cm}$ in length (Figure 1), was then introduced into the oral cavity of the animal with its most elongated edge facing upwards, and attached to the upper incisors, aiming to maintain the animal's oral cavity open during the procedure.

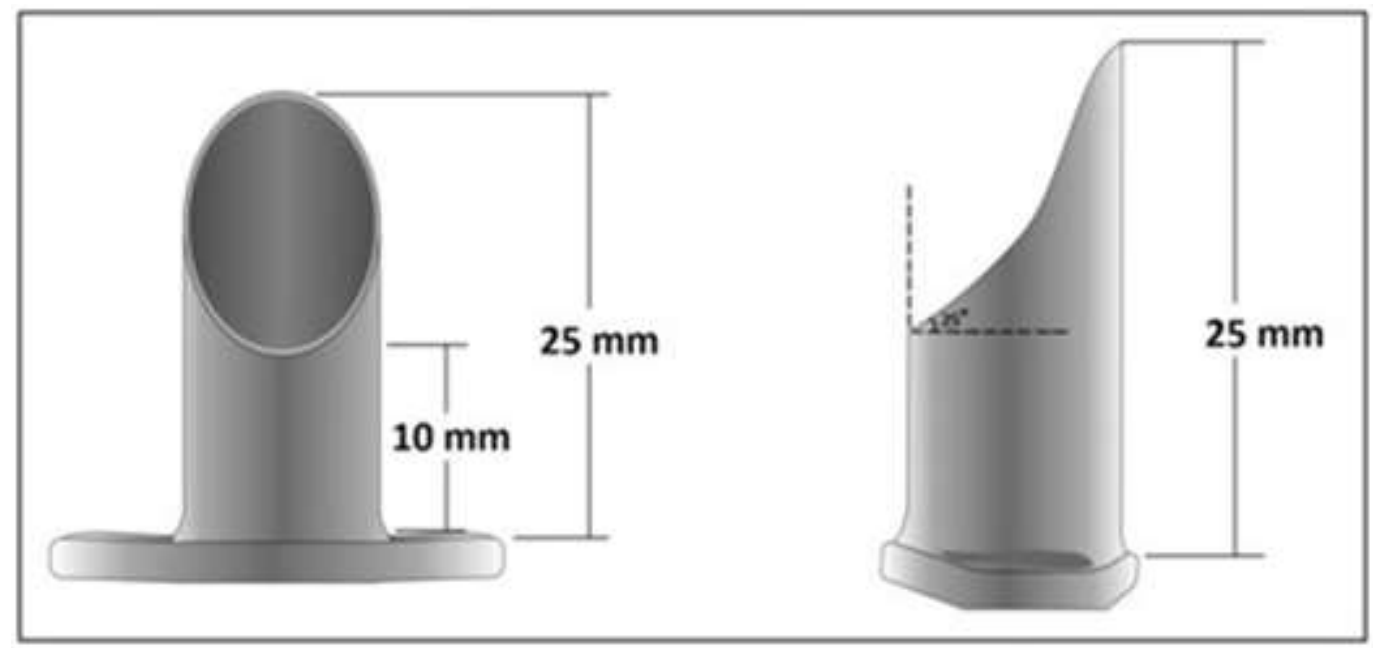

Figure 1 - Wedge to be inserted into the oral cavity of the animal. Made from a $3 \mathrm{~mL}$ syringe

Using tweezers, the animal's tongue was moved to its left and a light source (LED) was positioned in the neck of the animal (percutaneous transillumination) for better viewing of the trachea (Figure 2). 


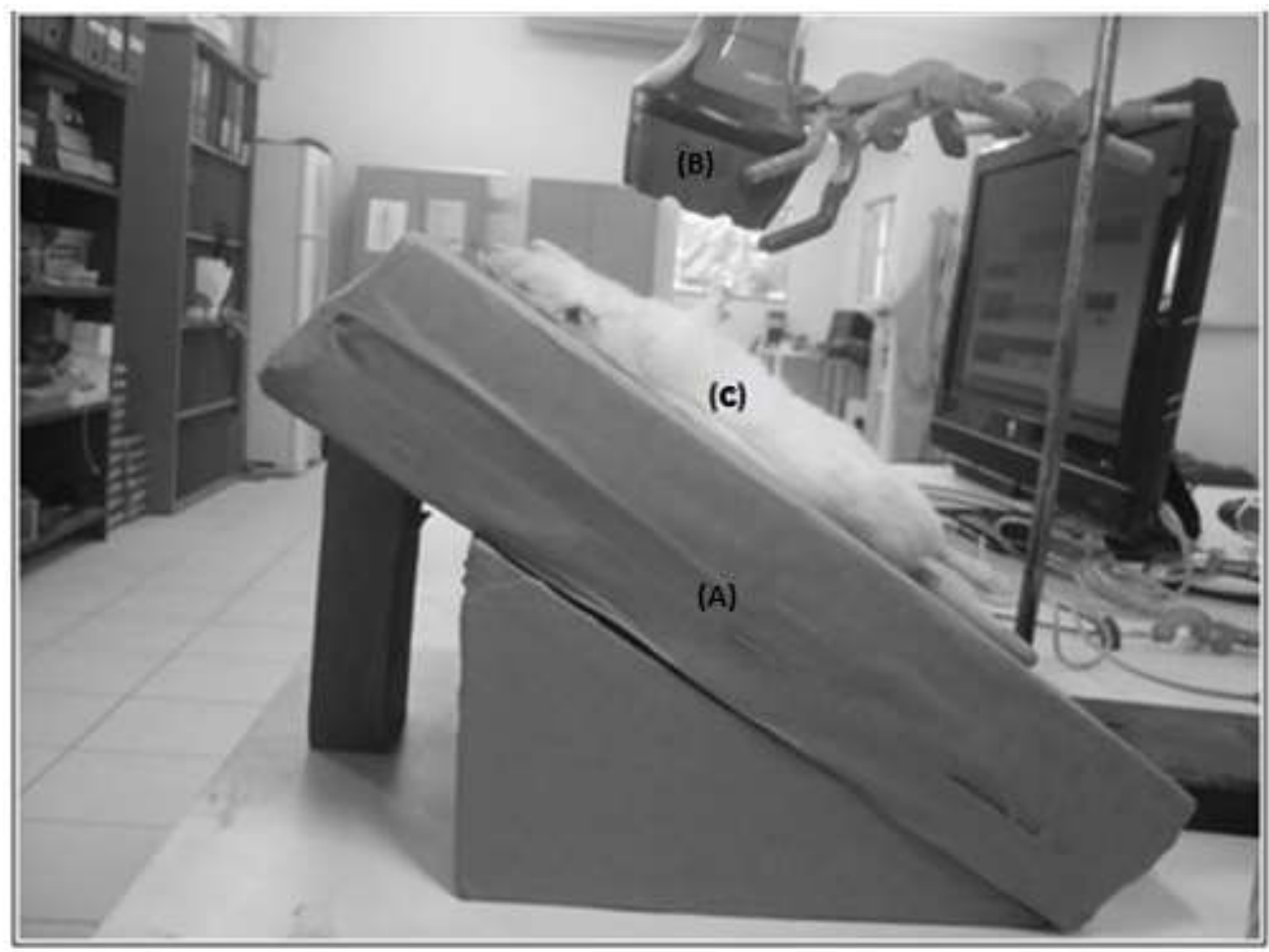

Figure 2 - Percutaneous transillumination. (A) tilted bed. (B) light source; (C) animal positioned in supine position, fixed by the incisors

Then, with the index finger and left thumb, the operator holds the edges of the wedge and places it properly for better visualization of the tracheal lumen, which will appear as the biggest bright spot within the oral cavity of the animal (Figure 3).

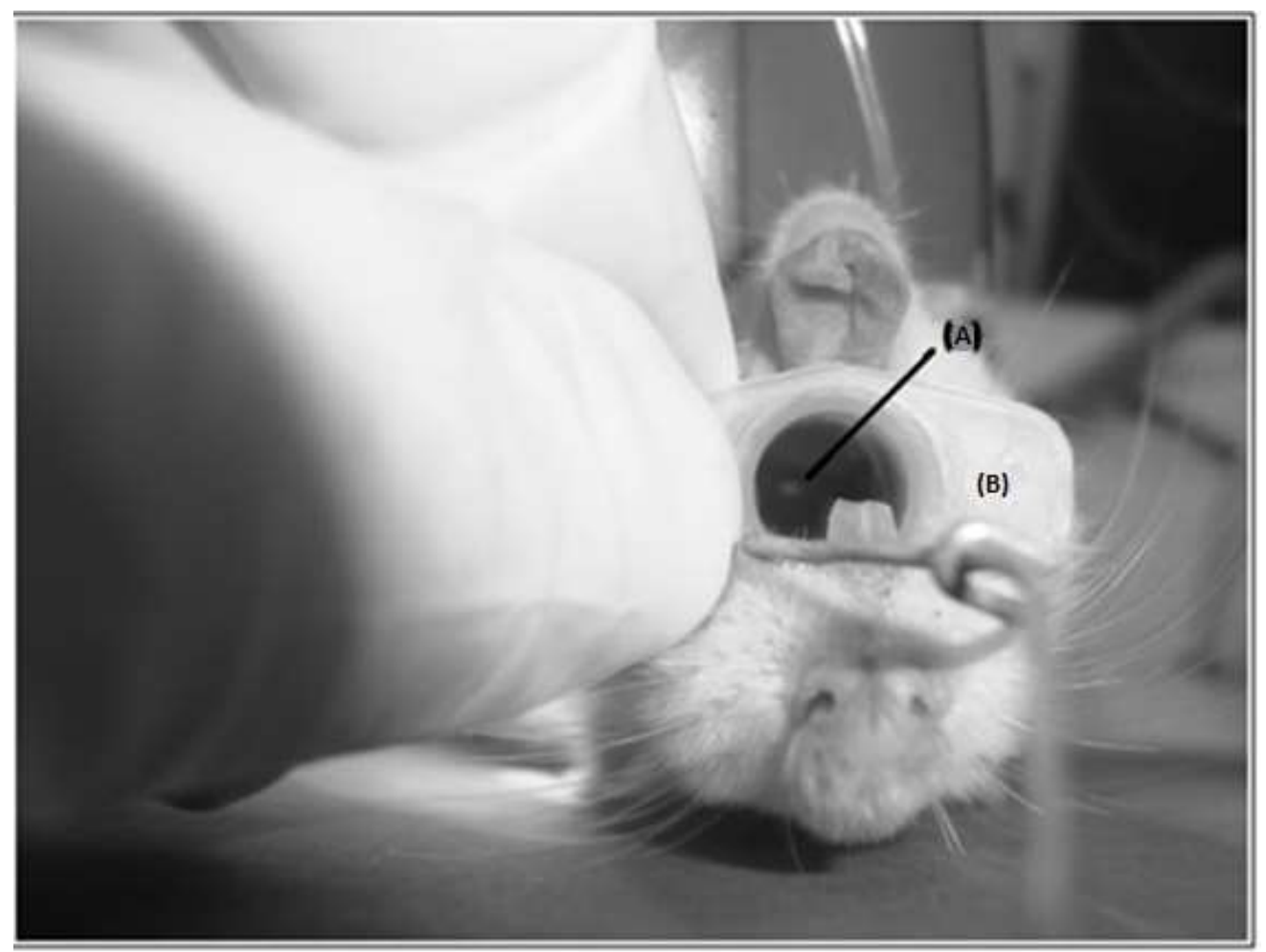

Figure 3 - Oral cavity of the animal placed in an inclined bed. (A) Tracheal lumen; (B) Wedge 
A guide wire (surgical steel) inserted within the 14gauge cannula (Eastern Medikit LTD) with a length of about $5 \mathrm{~mm}$ larger than the cannula (Figure 4) was first inserted into the tracheal lumen and removed upon insertion of the cannula in the trachea. The correct placement of the cannula in the trachea could be confirmed by the formation of condensation of water generated by the expiration of the rat on a mirrored surface. After this confirmation, the wedge was then removed and the cannula was attached to the animal with cotton thread. The cannula was then connected to the ventilator for small animals $\left(\mathrm{Scirec}^{\odot}\right.$ flexVent $t^{\circ}$ to perform the lung function measurements.

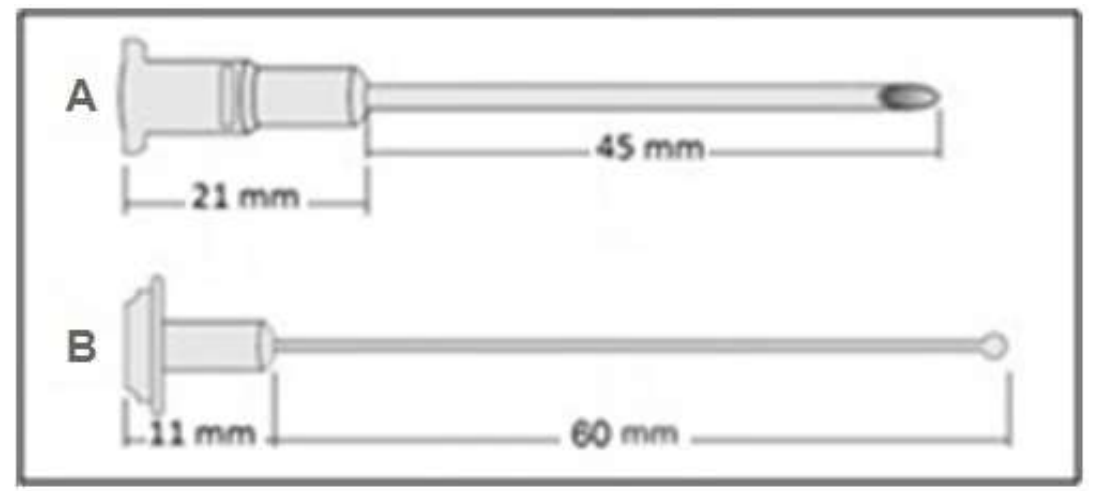

Figure 4 - Tracheal cannula $(A)$ and guidewire $(B)$ to be inserted into the tracheal lumen

\section{Tracheostomy}

For tracheostomy, the animals were anesthetized with sodium pentobarbital $(50 \mathrm{mg} / \mathrm{kg}$, 3\% Hypnol, Syntect, Brazil), intraperitoneally and positioned supine, attached to a surgical table and stabilized by its members with tape. Then, a tracheostomy was performed to introduce a cannula of 14 gauge (Medikit, India) which was fixed at the trachea by means of silk thread. The cannula was then connected to the ventilator for small animals $\left(\operatorname{Scirec}^{\odot}\right.$-flexVent $)$ and then made the measures related to lung function.

\section{Analysis of Lung Mechanics}

A mechanical ventilator for small animals (Scirec ${ }^{\circ}$ flexVent ${ }^{\circ}$ ) with measurements by the forced oscillation technique and pressure-volume curve was used to compare these values. The forced oscillation technique is an advanced model of lung mechanics which offers a distinction between central and peripheral respiratory mechanics. This model expresses separately the effects of airway resistance $\left(R_{n}\right)$, tissue resistance $(G)$, tissue elastance $(H)$ and hysteresivity $(\eta)$, values of static compliance $\left(C_{S T}\right)$ obtained by pressure-volume curve, an estimate of inspiratory capacity (IC) and the area of the pressure-volume curve (hysteresis).

The animals were ventilated at baseline standards at a frequency of $90 \mathrm{breaths} / \mathrm{min}$, a tidal volume of 10 $\mathrm{mL} / \mathrm{kg}$, with limiting pressure of $30 \mathrm{cmH}_{2} \mathrm{O}$, and positive end expiratory pressure (PEEP) of $3 \mathrm{cmH}_{2} \mathrm{O}$. The animals have to be sedated and paralyzed during the lung function test protocol. For that, after initiation of ventilation, pancuronium bromide (0.5 $\mathrm{mL} / \mathrm{kg}$ Pancuron', Cristália, Brazil, i.p.) was applied.

Prior to measurements, the volume history of the lung was standardized with two 6-second deep inflations to a pressure limit of $30 \mathrm{cmH}_{2} \mathrm{O}$. The measurement protocol was performed with the 10 times forced oscillation technique and 5 pressurevolume curve, with a 30 -sec interval between the measurements. The protocol for data collection of lung function lasted about $10 \mathrm{~min}$. 


\section{Statistical analysis}

The data relating to comparative analysis of pulmonary function among the techniques of intubation and tracheostomy are presented as the mean ( \pm standard deviation). The differences between the values of groups were tested using the $t$ test ( $T$ group versus IT group and IT group versus IT-1W group). All statistical analyses were performed with SigmaPlot (Systat Software, Inc.). The value of $P<0.05$ was considered statistically significant.

\section{Results}

\section{New technique Intubation}

The intubation procedure was simple and quick, the insertion of the cannula into the trachea was easy, because the use of the wedge and percutaneous transillumination promoted a clear view of the epiglottis, vocal cords and tracheal lumen. With the endotracheal cannula in place, the animals were then coupled to a mechanical ventilator for small animals (Scireq $^{\odot}$-flexiVent ${ }^{\circ}$ ) for data analysis in pulmonary function. The average time for completion of the intubation procedure was approximately $30 \mathrm{sec}$, and despite the data collection protocol, pulmonary function was accomplished in just $10 \mathrm{~min}$ in all groups (T, IT, IT-1W). For extubation of animals of IT and IT-1W groups, it was necessary to wait for these animals to exhibit spontaneous respiratory movements. Only then were they removed from the mechanic ventilator and extubated after signs of a full recovery.

No animal died during the intubation procedure. Approximately $76.67 \%$ of the animals were intubated at the first attempt, $13.33 \%$ at the second attempt, $6.67 \%$ at the third attempt, and $3.33 \%$ over three attempts.

As shown in Figure 5, the linear correlation between the time required for the intubation procedure and the weight of the animal was negatively significant.

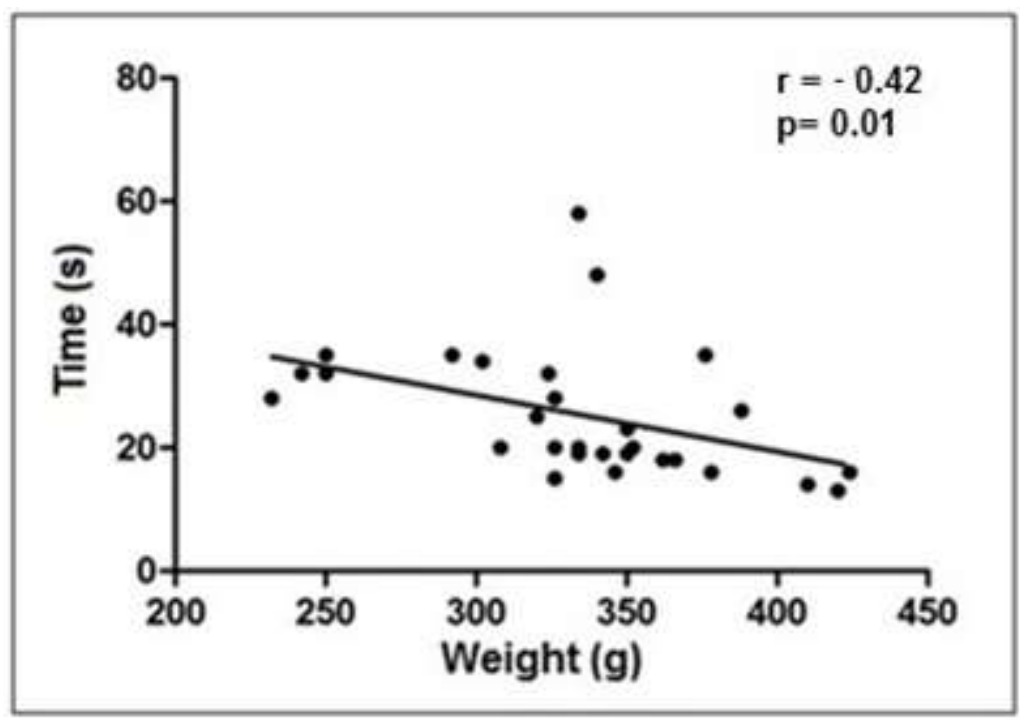

Figure 5 - Correlation between time to perform intubation and body weight

\section{Comparative analysis}

Data relating to the maneuvers of forced oscillation technique and pressure-volume curve are shown in Table 1. No significantly different values between groups in all studied variables were obtained. The performance of a second intubation did not significantly affect the data analyzed, as demonstrated by the results of the group IT-1W.

Table 1 - Differences between lung function parameters - Ceará, 2015 


\begin{tabular}{|c|c|c|c|c|c|}
\hline \multirow{2}{*}{$\begin{array}{l}\text { Measure } \\
\text { forced oscillation } \\
\text { technique }\end{array}$} & \multirow{4}{*}{$\begin{array}{l}\text { Airway resistance }\left(R_{N}\right) \\
\left(\mathrm{cmH}_{2} \mathrm{O} . \mathrm{s} / \mathrm{mL}\right)\end{array}$} & \multirow{2}{*}{$\frac{\text { Group }}{T}$} & \multirow{2}{*}{$\frac{\text { Value }}{0.08 \pm 0.02}$} & \multicolumn{2}{|c|}{$P$ value Student's test t } \\
\hline & & & & $\mathrm{T} \times \mathrm{IT}$ & 0.68 \\
\hline & & IT & $0.07 \pm 0.02$ & $\mathrm{~T} \times \mathrm{IT}-1 \mathrm{~W}$ & 0.84 \\
\hline & & IT-1W & $0.07 \pm 0.01$ & IT $x$ IT-1W & 0.76 \\
\hline & Tissue damping $(G)$ & $\mathrm{T}$ & $0.69 \pm 0.18$ & Tx IT & 0.51 \\
\hline & $\left(\mathrm{cmH}_{2} \mathrm{O} / \mathrm{mL}\right)$ & IT & $0.73 \pm 0.08$ & Tx IT-1W & 0.96 \\
\hline & & IT-1W & $0.69 \pm 0.12$ & IT x IT-1W & 0.41 \\
\hline & Tissue elasticity $(H)$ & $\mathrm{T}$ & $3.83 \pm 0.63$ & TxIT & 0.43 \\
\hline & $\left(\mathrm{cmH}_{2} \mathrm{O} / \mathrm{mL}\right)$ & IT & $4.05 \pm 0.47$ & Tx IT-1W & 0.73 \\
\hline & & IT-1W & $3.91 \pm 0.30$ & IOT x IT-1W & 0.50 \\
\hline & Hysteresivity ( $\eta$ ) & $\mathrm{T}$ & $0.17 \pm 0.04$ & Tx IOT & 0.84 \\
\hline & & IT & $0.18 \pm 0.05$ & Tx IOT-1W & 0.63 \\
\hline & & IT-1W & $0.19 \pm 0.06$ & IOT x IOT-1W & 0.77 \\
\hline \multirow[t]{9}{*}{ PV-curve } & $C_{S T}$ & $\mathrm{~T}$ & $0.80 \pm 0.17$ & Tx IOT & 0.90 \\
\hline & $\left(\mathrm{mL} / \mathrm{cmH}_{2} \mathrm{O}\right)$ & IT & $0.81 \pm 0.13$ & Tx IOT-1W & 0.95 \\
\hline & & IT-1W & $0.79 \pm 0.16$ & IOT x IOT-1W & 0.84 \\
\hline & $\mathrm{Cl}$ & $\mathrm{T}$ & $8.38 \pm 1.31$ & Tx IOT & 0.98 \\
\hline & $(\mathrm{mL})$ & IT & $8.36 \pm 1.08$ & Tx IOT-1W & 0.77 \\
\hline & & IT-1W & $8.72 \pm 1.27$ & IOT x IOT-1W & 0.62 \\
\hline & Hysteresis & $\mathrm{T}$ & $74.53 \pm 12.38$ & TxIOT & 0.67 \\
\hline & (area) & IT & $71.18 \pm 12.28$ & Tx IOT-1W & 0.88 \\
\hline & & IT-1W & $73.33 \pm 13.42$ & IOT x IOT-1W & 0.79 \\
\hline
\end{tabular}

The Student t test was performed for statistical analysis. $P<0.05$ was considered statistically significant. Data are presented as mean \pm standard deviation. $C_{\text {st: }}$ static compliance; $\mathrm{Cl}$ : estimated inspiratory capacity; Hysteresis: difference in the pressure-volume relationship during the inflation and deflation curve of a PV-loop

\section{Discussion}

The present study investigates the success rate of intubation in rats and the possible use of tracheostomy or intubation for collection of lung function in rats using the forced oscillation technique and pressurevolume curve by using the mechanic ventilator for small animals (Scirec ${ }^{\odot}$-flexVent $)$. The forced oscillation technique is widely used in the literature as it separates the resistive component of the airways $\left(R_{n}\right)$ components of the lung parenchyma $(G, H)$, providing a better physiological view of how a particular intervention affects the lungs. Already the pressurevolume curve provides quantifiable changes related to lung alveolar surfactant.

The results of the present investigation showed an excellent success rate in achieving intubation technique (100\%) and observed that all pulmonary function variables studied here can be collected using the intubation or tracheostomy, even repeatedly, without any changes caused by the chosen technique.

Intubation is an essential procedure in studies involving various surgeries that require survival of the animal, such as thoracotomy, heart surgery or their respiratory function analysis through use of a mechanical ventilator. Several procedures or equipment are cited by authors in order to facilitate intubation technique. The use of a bed inclined at $30^{\circ}$ is suggested by some authors (ABRÃO et al., 1994; LIZIO et al., 2001; ALZABEN et al., 2009) and this promotes a good positioning of the animal, improving the visualization of its oral cavity structures. A wedge made from a $3 \mathrm{~mL}$ syringe has been reported previously in the literature (LINDEN et al., 2000), aiding in maintaining the oral cavity of the animal open. The percutaneous transillumination has also been reported in the literature (LIZIO et al., 2001; 
IKEDA et al., 2009) and provides better visualization of the trachea through the oral cavity of the animal.

Despite previous training, the first attempts to perform the orotracheal intubation technique were not successful. First, reproducing the blind intubation (STARK et al., 1981) was tried, in which intubation was performed using a catheter with a modified angulation. This was inserted "blindly" into the trachea without direct visualization, but the rate of intubation was inferior to those cited in the study (90\%). It was concluded that this was a very traumatic procedure to the animal and with low success rates. Subsequently, we performed the technique using a wedge made from a 3-mL syringe (JOU et al., 2000). Despite the presence of the wedge to facilitate the technique, it was difficult to view the trachea, requiring numerous attempts before the procedure was successful. Several other techniques reported in the literature were also studied, but generally the observation reinforced the need for specially designed equipment that either had high cost, or required adaptations that were not very well described.

With respect to the number of attempts for correct intubation, the proposed technique showed that $76.67 \%$ of the animals were intubated on the first attempt, while $23.33 \%$ needed more than one attempt to perform the technique. In attempts in which intubation was not confirmed, we observed that the cannula was inserted accidentally inside the esophagus of the animal. This could be verified by a swallowing reflex exacerbated as the cannula was inserted, and the absence of condensation of water in a mirrored surface by the absence of exhaled air at the outer end of the cannula. However, it was concluded that this accidental insertion of the tube into the esophagus has not resulted in significant damage to animals, since there was no sign of blood secretion in these animals and after extubation all could eat normally after full recovery from anesthesia.

No histological analysis of tracheal smooth muscle to assess the presence of injury was performed. However, it was demonstrated that the tracheal smooth muscle of rats submitted to the intubation procedure showed no histological signs of injury (KONNO et al., 2014). It seems that the relatively short period in which the animal is subjected to the procedure is not enough to cause damage to the tracheal smooth muscle. However, it is suggested that the interval between repeated intubation is at least one week in order to avoid inflammatory damage (DE VLEESCHAUWER et al., 2011). Although the influence of repeated intubations and anesthesia on food intake and body weight of the animals was not analyzed, it is known that the period of one week between the procedures of intubation is sufficient to not provide significant changes in these parameters (DE VLEESCHAUWER et al., 2011).

The present study used rats with widely varying body weight, aiming to determine a higher weight range so that we could safely use the wedge. There were no problems in its use in animals studied with variation of weight $(300 \pm 70 \mathrm{~g})$. This variation was defined because most research analysis of pulmonary function in rats under mechanical ventilation use animals weighing $250 \pm 50 \mathrm{~g}$.

The results obtained from the correlation between necessary time to completion of intubation and the weight of the animal corroborates another study (HAMACHER et al., 2008), showing a negative correlation between these variables. Results are readily understood, since the higher the weight of the animal, the greater will be its oral cavity structures, thereby facilitating intubation.

For the collection of variables that measure lung function, this study used tracheostomy and intubation, which have the same purpose, introducing a cannula into the tracheal lumen targeting the engagement of the animal in mechanical ventilator. In the case of comparative analysis, a study was conducted to check for changes in lung function of rats suffering repeated intubations (HEULITT et al., 2008). The study used two groups of mice at various ages of development, lung function measurements were collected using the forced oscillation technique 
(constant phase model) and found no statistically significant differences between the studied variables. These results corroborate with the obtained in the present investigation, but in their study, there were no reports of intubation technique that was used.

Another comparative study explored if intubation can overcome the need for tracheostomy allowing invasive monitoring lung function in mice over time (DE VLEESCHAUWER et al., 2011). In the study, a group of animals were submitted to successive intubations (day 0, 10 and 20) and other groups were tracheostomized in the same period (day 0, 10 and 20) and then the pulmonary function parameters were collected. At work, they used two devices for collection of pulmonary function variables using the $\mathrm{Scirec}^{\odot}$ flexVent ${ }^{\circ}$ and $\mathrm{Buxco}^{\odot}$ - forced pulmonary maneuvers. Regarding the results obtained from the use of $\operatorname{Scirec}^{\Theta_{-}}$ flexVent, the authors reported that it was not possible to collect the variables of the technique of forced oscillations in the intubated animals due to the presence of spontaneous respiration. In the present study, this problem was not observed because a paralyzing muscle (Pancuron', Cristália, Brazil) was used prior to data collection. The authors did not report the way intubation technique was performed in their study.

The present study compared the pulmonary function parameters for the model of constant phase and pressure-volume curve between the T, IT and IT$1 \mathrm{~W}$ groups. The data show that airway resistance $\left(R_{n}\right)$,

\section{References}

ABRÃO, J.; SILVA, V. J. D.; REIS, L. C.; FAGUNDES, D. J. Proposição de um laringoscópio (artesanal) para intubação traqueal em ratos. Acta Cirúrgica Brasileira, v. 9, n. 3, p. 136-141, 1994.

ALZABEN, K. R.; ABU-HALAWEH, S. A.; ALOWEIDI, A. K. S.; ISMAIL, Z. A. B.; AL-AMMOURI, I. A.; AL-ESA, M. K.; JABAITI, S. K.; ALSMADY, M. M.; ABU-ABEELEH, M. Use of the nasal speculum for rat endotracheal intubation. tissue resistance $(G)$, tissue elastance $(H)$, hysteresivity $(\mathrm{n})$, static compliance $\left(C_{S T}\right)$, an estimate of inspiratory capacity $(I C)$ and hysteresis resulted in average values with no statistically significant differences.

Regarding the $\mathrm{T}$ group versus IT group, the observation of absence of statistical significance between the values of these groups shows that the type of technique used to access the airways of animals will not influence the values of lung function. Intubation may be used as an alternative to tracheostomy without changing the obtained results. Furthermore, no statistical significance between the group IT and IT$1 \mathrm{~W}$ group shows that successive intubations can be performed without causing changes in the values of lung function. These findings show that intubation can be used in research on the progression of lung disease, for example.

In conclusion, the proposed technique of intubation can be easily learned, played and used and the implications of such a technique can be generalized to all labs that deal with intubation of rats. This technique is a safe alternative to studies using inhalation anesthesia that perform lung function measurements in mechanical ventilator or monitoring aimed at different evolutionary models of chronic respiratory diseases. The work strengthens an ethical issue to develop appropriate experimental designs aimed at reducing the number of animals used in research.

American Journal of Applied Sciences, v. 6, n. 3, p. $507-$ 511, 2009. doi: 10.3844/ajassp.2009.507.511.

CLARY, E. M.; O'HALLORAN, E. K.; FUENTE, S. G. de la; EUBANKS, S. Videoendoscopic endotracheal intubation of the rat. Laboratory Animals, v. 38, n. 2, p. 158-161, 2004. doi: $10.1258 / 002367704322968830$.

DE VLEESCHAUWER, S. I.; RINALDI, M.; DE VOOGHT, V.; VAINOIRBEEK, J. A.; VANAUDENAERD, B. M.; 
VERBEKEN, E. K.; DECRAMER, M.; GAYAN-RAMIREZ, G. N.; VERLEDEN, G. M.; JANSSENS, W. Repeated invasive lung function measurements in intubated mice: an approach for longitudinal lung research. Laboratory Animals, v. 45, n. 2, p. 81-89, 2011. doi: 10.1258/la.2010.010111.

HAMACHER, J.; ARRAS, M.; BOOTZ, F.; WEISS, M.; SCHRAMM, R.; MOEHRLEN, U. Microscopic wire guidebased orotracheal mouse intubation: description, evaluation and comparison with transillumination. Laboratory Animals, v. 42, n. 2, p. 222-230, 2008. doi: 10.1258/la.2007.006068.

HEULITT, M. J.; JONES, S. M.; HOLT, S. J.; THURMAN, T. L.; JO, C. H.; SIMPSON, P. M. Repeated measurements of respiratory mechanics in developing rats utilizing a forced oscillation technique. Experimental Lung Research, v. 34, n. 7, p. 409-423, 2008. doi: $10.1080 / 01902140802222084$.

IKEDA, A.; MATSUSHITA, S.; SAKAKIBARA, Y. A simple and reliable method of endotracheal intubation in mice: advantages of exposing the trachea. Scandinavian Journal of Laboratory Animal Science, v. 36, n. 4, p. 363368, 2009.

JOU, I. M.; TSAI, Y. T.; TSAI, C. L.; WU, M. H.; CHANG, H. Y.; WANG, N. S. Simplified rat intubation using a new oropharyngeal intubation wedge. Journal of Applied Physiology, v. 89, n. 5, p. 1766-1770, 2000.
KASTL, S.; KOTSCHENREUTHER, U.; HILLE, B.; SCHMIDT, J.; GEPP, H.; HOHENBERGER, W. Simplification of rat intubation on inclined metal plate. Advances in Physiology Education, v. 28, n. 1-4, p. 29-32, 2004.

KONNO, K.; SHIOTANI, Y.; ITANO, N.; OGAWA, T.; HATAKEYAMA, M.; SHIOYA, K.; KASAI, N. Visible, safe and certain endotracheal intubation using endoscope system and inhalation anesthesia for rats. Journal of Veterinary Medical Science, v. 76, n. 10, p. 1375-1381, 2014. doi: 10.1292/jvms.14-0146.

LINDEN, R. D.; SHIELDS, C. B.; ZHANG, Y. P.; EDMONDS, H. L.; HUNT, M. A. A laryngoscope designed for intubation of the rat. Contemporary Topics in Laboratory Animal Science, v. 39, n. 2, p. 40-42, 2000.

LIZIO, R.; WESTHOF, A.; LEHR, C. M.; KLENNER, T. Oral endotracheal intubation of rats for intratracheal installation and aerosol drug delivery. Laboratory Animals, v. 35, n. 3, p. 257-260, 2001. doi: $10.1258 / 0023677011911723$.

MACDONALD, K. D.; CHANG, H. Y. S.; MITZNER, W. An improved simple method of mouse lung intubation. Journal of Applied Physiology, v. 106, n. 3, p. 984-987, 2009. doi: 10.1152/japplphysiol.91376.2008.

STARK, R. A.; NAHRWOLD, M. L.; COHEN, P. J. Blind oral tracheal intubation of rats. Journal of Applied Physiology, v. 51, n. 5, p. 1355-1356, 1981. 